Provided for non-commercial research and education use. Not for reproduction, distribution or commercial use.

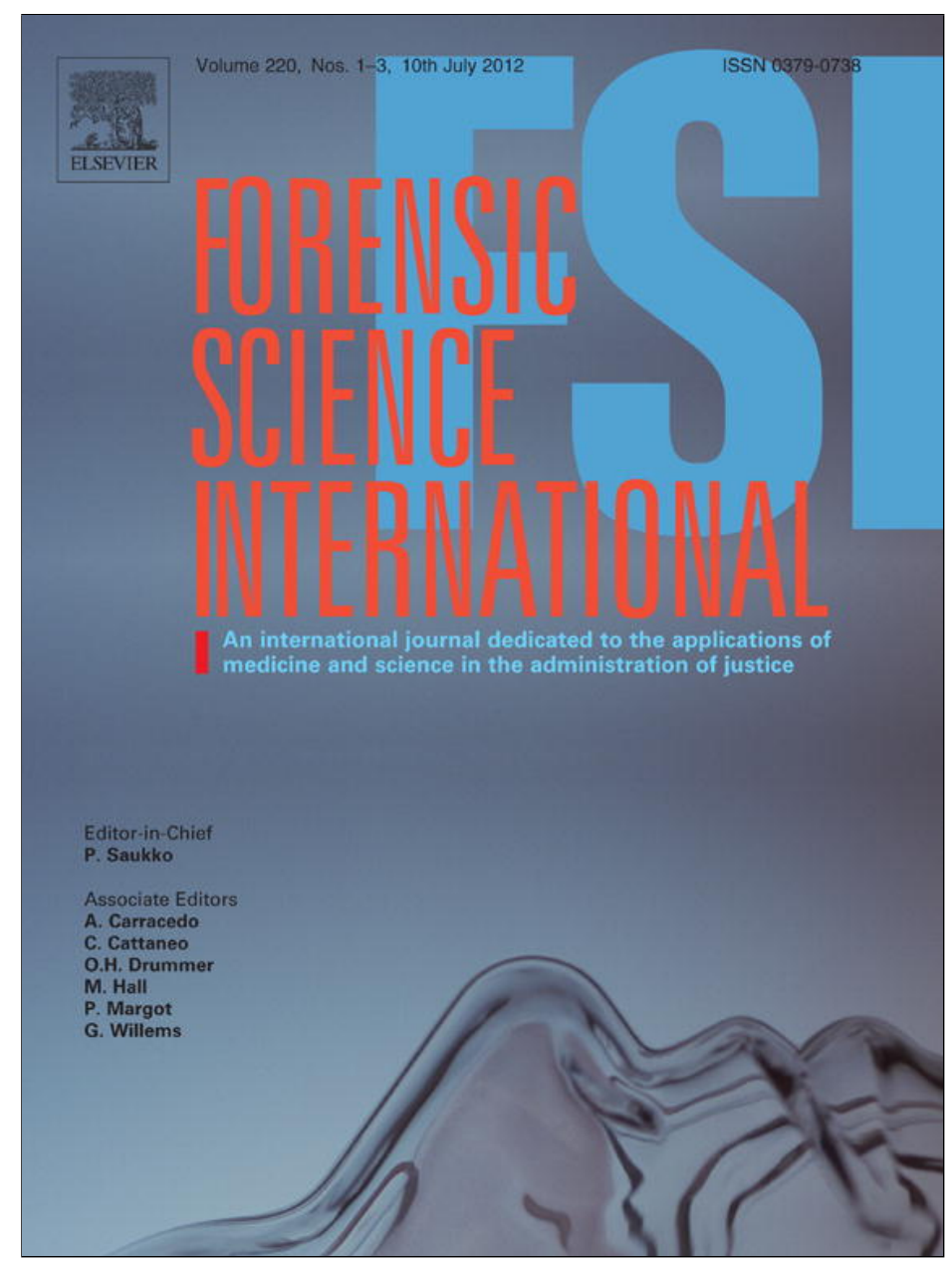

This article appeared in a journal published by Elsevier. The attached copy is furnished to the author for internal non-commercial research and education use, including for instruction at the authors institution and sharing with colleagues.

Other uses, including reproduction and distribution, or selling or licensing copies, or posting to personal, institutional or third party websites are prohibited.

In most cases authors are permitted to post their version of the article (e.g. in Word or Tex form) to their personal website or institutional repository. Authors requiring further information regarding Elsevier's archiving and manuscript policies are encouraged to visit:

http://www.elsevier.com/copyright 


\title{
Occurrences of flesh flies (Diptera: Sarcophagidae) on human cadavers in Switzerland, and their importance as forensic indicators
}

\author{
Daniel Cherix ${ }^{\mathrm{a}, \mathrm{b}, *}$, Claude Wyss $^{\mathrm{a}}$, Thomas Pape ${ }^{\mathrm{c}}$ \\ ${ }^{a}$ Museum of Zoology, Pl. de la Riponne 6-CP, CH-1014 Lausanne, Switzerland \\ ${ }^{\mathrm{b}}$ University of Lausanne, Department of Ecology and Evolution, Biophore, CH-1015 Lausanne, Switzerland \\ ${ }^{\mathrm{c}}$ Natural History Museum of Denmark, Universitetsparken 15, DK-2100 Copenhagen, Denmark
}

\section{A R T I C L E I N F O}

\section{Article history:}

Received 8 December 2010

Received in revised form 2 November 2011

Accepted 23 February 2012

Available online 31 March 2012

\section{Keywords:}

Forensic entomology

New records

Post-mortem interval estimation

Sarcophaga

Sarcophagidae

\begin{abstract}
A B S T R A C T
From 1993 to 2008, criminal investigations were conducted in the western part of Switzerland with special attention to blowfly and flesh fly species in order to estimate the post-mortem interval when requested by the police authorities. Flesh flies were found in only 33 cases out of 160 . Five species of the genus Sarcophaga were identified (S. africa, S. argyrostoma, S. caerulescens, S. similis and S. sp.). The main species found on corpses (larval stage) was S. argyrostoma. The thermal constant $(K)$ calculated for this species in Switzerland is $380.6 \pm 16.3$ (mean \pm S.D.) degree-days. With the exception of S. caerulescens, found three times in the larval stage on corpses, the three other species are of minor forensic importance. $S$. argyrostoma is found during summer and indoors. This species colonises dead bodies, usually the same day as blowfly species, and it could be used to estimate the post-mortem interval. Other species are discussed in the light of current knowledge on their biology and ecology. It is recommended that voucher material be deposited in a museum, allowing further studies by relevant specialists, thereby helping investigators and avoiding misidentifications.
\end{abstract}

(c) 2012 Elsevier Ireland Ltd. All rights reserved.

\section{Introduction}

Forensic entomology, defined as the use of insects and other arthropods in criminal and other legal investigations, has been growing in importance during the last decades. Since the basic work of Mégnin [1] numerous articles have been published on forensic entomology, and books like those of Leclercq [2], Smith [3], Catts and Haskell [4], Erzinçlioglu [5], Byrd and Castner [6,7], Greenberg and Kunich [8], Wyss and Cherix [9] and Gennard [10] and Amendt et al [11] have appeared within the last 30 years.

The foundation necessary for a reliable application of forensic entomology was mostly laid down during the first half of the 20th century by taxonomists interested in those insect species of forensic importance. These belong in particular to two principal dipteran families: the Calliphoridae (blowflies) and the Sarcophagidae (flesh flies). Many blowflies of the genera Calliphora, Chrysomya, Cynomya, Lucilia, Phormia and Protophormia lay their eggs on dead bodies of various animals, especially vertebrates, including humans. Because calliphorid flies have been recorded as arriving at dead bodies within minutes of their exposure, they

\footnotetext{
* Corresponding author at: Department of Ecology and Evolution, University of Lausanne, Biophore, CH-1015 Lausanne, Switzerland. Tel.: +41 213163462 fax: +41213163479.

E-mail address: daniel.cherix@unil.ch (D. Cherix).
}

provide very reliable information relating to the estimation of the post-mortem interval (PMI).

About 52 species of blowflies have been recorded in Switzerland [12], but only a dozen are true necrophagous species that may be breeding in corpses [9]. Thanks to the work of Rognes $[13,14]$, these species can be precisely identified in Europe.

While we can often use calliphorid flies for accurate estimates of PMI, the situation is very different with the sarcophagid flies. Most flesh flies are very difficult to identify in almost all life stages, and especially in the larval stages found on carrion. This has led to some curious results in articles dealing with forensic entomology. Some recent studies, like the ones by Archer and Elgar [15], Cainé et al. [16] and Charabidze et al. [17], indicate only Sarcophagidae or Sarcophaga sp., but no species identifications are made. Others provide identifications that are highly unlikely, like Vanin et al. [18] reporting Sarcophaga protuberans bred from a human cadaver (subsequent identification of vouchers revealed these to be Sarcophaga argyrostoma; D. Whitmore, personal communication). Following Pape $[19,20]$, most necrophagous species fall within the subfamily Sarcophaginae, although a few species of Miltogramminae show [21]. However, there is a cruel deficiency of information not only about species identification, but also about the biology and behaviour of flesh flies. Moreover, we can often think of misidentification of species, which are clearly not necrophagous. For example, Orfila [22] listed 30 species of insects and other arthropods that visited corpses to feed and oviposit; 
Table 1

Species of Sarcophagidae discovered on human corpses in Switzerland.

\begin{tabular}{|c|c|c|c|c|c|}
\hline Species & Total number of cases & Adult (no of cases) & Immature (no of cases) & Indoors (no of cases) & Outdoors (no of cases) \\
\hline S. africa & 1 & 1 & - & 1 & - \\
\hline S. argyrostoma & 27 & 26 & 19 & 25 & 2 \\
\hline S. caerulescens & 3 & 3 & 3 & 1 & 2 \\
\hline S. similis & 1 & 1 & 1 & 1 & - \\
\hline S. $d u x$ & 1 & 1 & - & - & 1 \\
\hline Total & 33 & 31 & 23 & 28 & 5 \\
\hline
\end{tabular}

among them, we find Sarcophaga carnaria (Linnaeus). Some years later, Bergeret [23] established the probable time of death of an infant found in a bricked-up fireplace based on the presence of the flesh fly S. carnaria (most likely misidentified) and a moth. He wrongly assumed that both species were univoltine. Bergeret's reasoning was based on an incorrect assumption concerning the life cycles of both species and his estimation of the PMI was much too long. For Mégnin [1], only one species of Sarcophagidae was recognised: Sarcophaga carnaria. This species was also cited by Smith [3], who discussed the fact that some authors claim that this species feeds exclusively on earthworms. Available evidence would seem to indicate that species of Sarcophaga (sensu stricto) are predators on earthworms [24-27], although adults are attracted to both faeces and decaying meat $[28,29]$. It is therefore questionable to find larvae of S. carnaria in a case in Italy [30], in particular as larvae of Sarcophaga (sensu lato) cannot be identified by conventional means and no adults were stated to have been bred. Povolný and Verves [31] indicated that, as for the blowflies, only a limited number of flesh flies are involved in forensic cases and mentioned for Central Europe: Sarcophaga (Bercaea) cruentata Meigen, 1826 (syn. haemorrhoidalis auctt. not Fallén, 1817), Sarcophaga (Parasarcophaga) hirtipes Wiedemann, 1830, Sarcophaga (Liosarcophaga) dux Thomson, 1869 (usually misidentified as "misera" auctt. not Walker, 1849 or S. exuberans Pandellé, 1896 - a synonym of $S$. dux Thomson) and closely related species (e.g. Sarcophaga (Liosarcophaga) tibialis Macquart, 1850, Sarcophaga (Liosarcophaga) jacobsoni Rohdendorf, 1937, Sarcophaga (Liopygia) crassipalpis Macquart, 1839 and Sarcophaga (Liopygia) argyrostoma (Robineau-Desvoidy, 1830)). Some of these species are only occasionally breeding in carrion and therefore of little importance in forensic investigations. Only three taxa are consistently necrophagous (S. crassipalpis, S. argyrostoma and S. dux) and data are available on their successful rearing not only from dead bodies of vertebrates, but also from dead invertebrates, particularly snails [31]. Our aim is to give a detailed analysis of the Sarcophagidae collected during 15 years of criminal investigations in Switzerland and to show and discuss the limits of using them in estimations of the PMI.

\section{Materials and methods}

During 1993-2007, in the canton de Vaud (southwestern part of Switzerland) and the surrounding area, 160 criminal investigations involving entomological expertise were conducted [9]. Immature stages of Sarcophagidae collected on corpses were reared in the laboratory under controlled conditions to the adult stage. Adult specimens, either from rearing in the laboratory or collected at the crime scene, were preserved by conventional killing and pinning, labelled and then deposited in the entomological collection of the Museum of Zoology in Lausanne. Specimens were identified based on their terminalia and relying on a combination of the keys by Pape [19] and Povolný and Verves [31] and the reference collection at the Zoological Museum, University of Copenhagen. Other species of flies (mainly blowflies) collected with the flesh flies were identified by us with the works of Rognes $[13,14]$ and likewise deposited in the Museum of Zoology in Lausanne.

Collecting living material at the crime scene is made by handpicking of the larval stages into containers with some humidity or with an insect net for catching flying insects. When back in the laboratory, eggs and larvae are transferred into bigger containers with $1-2 \mathrm{~cm}$ of hamster litter and a piece of meat (liver) covered with humidified filter paper. Pupae are put in the same kind of container but without meat. These containers are placed individually in a bigger one with sand in order to prevent any of the maggots from escaping. The containers are stored in the dark in a controlled environment cabinet until the adult flies hatch (see Ref. [10] for a detailed description).

\section{Results}

Flesh flies were found at crime scenes in only 33 cases (20\%) out of 160 criminal investigations involving dead human bodies, while blowflies were present in more than $89 \%$ of the cases. Five species of Sarcophagidae were identified (see Table 1). Among them, one female specimen could not be identified. Only adult specimens of $S$. africa were collected.

Among these five species, $S$. argyrostoma can be considered as relatively frequent ( 27 cases) on corpses (i.e., dead human bodies), while the remaining four species are rarely collected (from 1 up to 3 times) on corpses. Moreover, most of the Sarcophagidae have been found indoors ( 28 cases against five). When pooling all the

Table 2

Selected cases where PMI was calculated with the help of blowflies (cases with * show a later arrival and larviposition of $S$. argyrostoma, cases with ** show an earlier arrival and larviposition of S. argyrostoma).

\begin{tabular}{|c|c|c|c|c|c|c|}
\hline Case number & $\begin{array}{l}\text { Day of body } \\
\text { discovery }\end{array}$ & $\begin{array}{l}\text { Species found at larval } \\
\text { stage and reared in } \\
\text { the laboratory }\end{array}$ & $\begin{array}{l}\text { Day of egg-laying } \\
\text { evaluation for the species } \\
\text { reared in the laboratory }\end{array}$ & $\begin{array}{l}\text { Day of larviposition } \\
\text { of S. argyrostoma }\end{array}$ & $\begin{array}{l}\text { Thermal constant } \\
\text { for S. argyrostoma } \\
\text { (degree-days) }\end{array}$ & $\begin{array}{l}\text { Number of days } \\
\text { for the development } \\
\text { of } S \text {. argyrostoma }\end{array}$ \\
\hline 2 & 9.8 .94 & L. sericata & 6.8 .94 & 6.8 .94 & 368.7 & 25 \\
\hline $22^{*}$ & 25.8.95 & Ch. albiceps & 17.08 .95 & 21.08 .95 & 396.7 & 29 \\
\hline 38 & 17.6.96 & L. sericata & 9.6 .96 & 9.6 .96 & 388.7 & 27 \\
\hline 42 & 17.7.96 & Me. rufipes & 13.7.96 & 13.7.96 & 379.5 & 26 \\
\hline 43 & 18.7.96 & Pr. terranovae & 3.7.96 & 3.7.96 & 369.9 & 30 \\
\hline $69^{*}$ & 24.05 .99 & Ca. vicina & 6.5 .99 & 15.5 .99 & 396.8 & 29 \\
\hline 106 & 11.06 .02 & Ca. vicina & 6.6 .02 & 6.6 .02 & 368.3 & 26 \\
\hline $109^{*}$ & 16.07 .02 & Ca. vicina & 12.7 .02 & 13.7 .02 & 399.2 & 28 \\
\hline 119 & 9.05 .03 & Ca. vicina & 28.4 .03 & 28.4 .03 & 389.2 & 28 \\
\hline 126 & 7.08 .03 & L. sericata & 3.8 .03 & 3.8 .03 & 394.6 & 25 \\
\hline 128 & 19.08 .03 & $\begin{array}{l}\text { L. sericata } \\
\text { L. caesar }\end{array}$ & 15.8 .03 & 15.8 .03 & 339.2 & 23 \\
\hline 130 & 25.08 .03 & Ca. vicina & 21.8 .03 & 21.8 .03 & 370.4 & 25 \\
\hline $139^{* *}$ & 19.6.04 & L. sericata & 10.06 .04 & 2.06 .04 & 386.8 & 29 \\
\hline
\end{tabular}




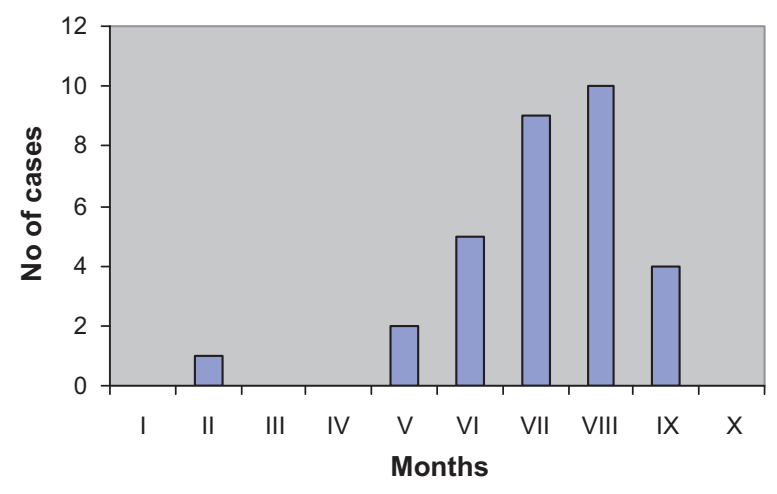

Fig. 1. Seasonal distribution of expertises with Sarcophaga species.

capture dates (Table 2), it is seen that about $60 \%$ of the cases involving sarcophagid flies are found in July and August, but flesh fly infestations can be encountered from May to September (Fig. 1).

Sarcophaga argyrostoma is the main species found on dead bodies in Switzerland, mostly in larger cities such as Lausanne and its suburbs (74\%), otherwise in smaller cities such as Yverdon (north of Lausanne, 11\%) and towns in the Rhone Valley (15\%). More than $90 \%$ of the cases involving this species were with corpses located inside buildings (in apartments), sometimes several floors high. Living adults as well as living larvae were discovered in $70 \%$ of the cases. S. argyrostoma was found in association with the following Calliphoridae: $\mathrm{Ca}$. vicina, $\mathrm{Ca}$. vomitoria, Ch. albiceps, Cy. mortuorum, L. ampullacea, L. caesar, $L$. illustris, L. sericata, Ph. regina and Pr. terranovae. Adults of $S$. argyrostoma are present in summer, with highest abundance in July and August. The earliest case in the year (February) was in an apartment with one dead body several months old, and the fly infestations probably occurred during autumn. Dead adults of $\mathrm{Ca}$. vicina, L. sericata, S. argyrostoma, Hydrotaea ignava and Muscina pabulorum were recovered. Empty pupariae of $\mathrm{Ca}$. vicina and $S$. argyrostoma with small holes, probably parasitised by the pteromalid wasp Nasonia vitripennis, were also discovered. The only living insects found were numerous black larder beetles (Dermestes haemorrhoidalis).

Among the 19 cases with S. argyrostoma (Table 1) where larvae were found on corpses and reared under laboratory conditions, we could select 13 cases suitable for evaluation of the PMI (Table 2). We used a minimum development threshold (tL) of $7.4^{\circ} \mathrm{C}$ as found by Grassberger and Reiter [32], and we obtained an overall thermal constant of $380.6 \pm 16.3$ (mean \pm S.D.) degree-days. Four cases present some interesting questions. In case 22, the first fly to emerge was Ch. albiceps, but we obtained Ca. vicina 3 days later (20th August) and $L$. sericata together with $S$. argyrostoma additionally 1 day later (21st August). This is interpreted as a delayed larviposition of flesh flies on the body (4 days later than the first blowfly). In case $69, S$. argyrostoma larviposited about 9 days later than the first blowfly ( $\mathrm{Ca}$. vicina), and the most likely explanation is that adult flesh flies were not present during the first days or could not reach the corpse immediately (see also Reibe and Maeda, [33]). Other evidence from the investigation showed that the person could have died even a week before the egg laying of $\mathrm{Ca}$. vicina (indicated by the mail still in the mailbox), but no clear conclusion could be made. Case 109 is developed subsequently. Finally, case 139 is quite different because this time $S$. argyrostoma was the first to emerge, about 10 days before $L$. sericata. The police was called to an apartment, and when they forced their way through the door, they found a nearly mummified body of a man lying on his bed with a rifle. All windows were closed and blinds in the room were down. According to the state of decomposition of the body, it was reasonable to conclude that $S$. argyrostoma was the first to colonise the body, shortly after the man committed suicide. Two cases are developed next as they are representative of situations involving S. argyrostoma.

\subsection{Case 109 (S. argyrostoma)}

On the 16th of July, lodgers of a multi-storey building, located in a suburban area close to the city of Lausanne (altitude $420 \mathrm{~m}$ ), called the police because of a foul smell coming from a third floor apartment. A naked corpse of a young male was discovered lying on the floor in the bathroom. Utensils from a person addicted to drugs were also discovered (syringes). The temperature in the room was $22{ }^{\circ} \mathrm{C}$. Adults of the following dipteran species were captured: $L$. caesar and Hydrotaea ignava as well as adult beetles of Creophilus maxillosus and Thanatophilus rigosus. Larvae of Diptera were found and collected under the corpse near the head. Other larvae were also collected at the Institute of Legal Medicine (University of Lausanne) the next day when the body was brought in for autopsy.

Larvae were reared in the laboratory and adults of $\mathrm{Ca}$. vicina did not emerge until the 1 st of August (17 days after the discovery of the body) and those of S. argyrostoma as late as the 9th of August (25 days after discovery). Using a thermal constant $(K)$ for $C a$. vicina of 388 degree-days $[9,34,35]$ the flies laid their first eggs on the 12 th of July $(K=391.4)$. If we use data from Grassberger and Reiter [32] the thermal constant for S. argyrostoma is $396.4 \pm 19.18$ (mean $\pm \mathrm{SD}$ ) degree-days with a minimum development threshold (tL) of $7.4{ }^{\circ} \mathrm{C}$. However, we obtained a thermal constant of 413.5 degree-days if the flies laid their larvae on the 12th of July, the same day as Ca. vicina. This is clearly too early. If we make the calculation based on larviposition 1 day later, the 13th of July, the thermal constant would be 399.2 degree-days, still a little bit too high according to our mean thermal constant. By subtracting another day, i.e., if $S$. argyrostoma larviposited on the 14 th of July, 2 days after $\mathrm{Ca}$. vicina, a $K$ value of 386 degree-days is obtained. In all estimations of PMI, we use $\pm 24 \mathrm{~h}$ as confidence interval, which in this case means that larviposition would have occurred between the 13th and the 15 th of July.

\subsection{Case 126 (S. argyrostoma)}

On the 7th of August, a naked body of a young female was recovered in an apartment located in a building in the city of Yverdon (north of Lausanne). The body was lying face down on the

Table 3

Selected cases with the presence of S. caerulescens where PMI was calculated with the help of blowflies.

\begin{tabular}{|c|c|c|c|c|c|c|}
\hline Case number & $\begin{array}{l}\text { Day of body } \\
\text { discovery }\end{array}$ & $\begin{array}{l}\text { Species found in larval } \\
\text { stage and reared } \\
\text { in the laboratory }\end{array}$ & $\begin{array}{l}\text { Day of egg-laying evaluation } \\
\text { for the species reared in the } \\
\text { laboratory }\end{array}$ & $\begin{array}{l}\text { Day of larviposition } \\
\text { of } S \text {. caerulescens }\end{array}$ & $\begin{array}{l}\text { Thermal constant for } \\
\text { S. caerulescens } \\
\text { (degree-days) } \\
\text { with } 7.4^{\circ} \mathrm{C}\end{array}$ & $\begin{array}{l}\text { Number of days } \\
\text { for the development } \\
\text { of S. caerulescens }\end{array}$ \\
\hline 77 & 13.9.99 & L. caesar & 13.9.99 & 13.9.99 & 312.3 & 24 \\
\hline 107 & 8.7 .02 & L. caesar & 2.7.99 & 2.7.99 & 335.7 & 29 \\
\hline 140 & 19.6.04 & Ca. vicina & 15.6 .04 & 15.6 .04 & 323 & 26 \\
\hline
\end{tabular}


floor. Part of the body was blackened. The death was probably due to suicide, as indicated by the presence of a razor blade close to the body, blood traces in the nearby sink and wounds on the arms. The local temperature on the day of the discovery was $28^{\circ} \mathrm{C}$. There were only larvae on the body. Samples of larvae were collected and reared in the laboratory under controlled conditions. On the 17th of August, the first adults to emerge belonged to $L$. sericata ( $K=207$ degree-days with tL $9{ }^{\circ} \mathrm{C}$ ). Ten days later (27th of August) adults of $S$. argyrostoma emerged. If the thermal constant is calculated following Grassberger and Reiter [32] with a minimum development threshold of $7.4{ }^{\circ} \mathrm{C}$, we reach 396.4 degree-days, indicating that the larvae were laid on the 3rd of August like the eggs of $L$. sericata, 5 days before the discovery of the body. However, using our thermal constant of 380.6 in the calculation, larviposition would have been 1 day later, 4 days before the discovery of the body. In this case, $S$. argyrostoma was giving about the same result as L. sericata.

Sarcophaga caerulescens was found in three cases and only in the larval stage: one case in an apartment and two cases in a more natural environment (clearing in a forest and at the edge of a forest). This species was associated with Ca. vomitoria, L. caesar and L. illustris. The entire development to the adult stage requires between 508 and 610 degree-days (between 25 and 29 days in the Swiss summer; C. Wyss, unpublished). In one case, larvae were deposited on the day of death, within an hour before the arrival of the police. This case involved a man who committed suicide in the morning, and a witness called the police immediately. It is difficult to assess the affinity of this species to corpses found indoors, but as two cases out of three were outdoors, we can predict a different behaviour compared to S. argyrostoma.

We have only three cases to analyse and to discuss (see Table 3) but one of them (case 77) is very interesting and furthermore presents a good evaluation of the development of this species. We assume that the minimum development threshold for the species is $7.4{ }^{\circ} \mathrm{C}$.

\subsection{Case 77 (S. caerulescens)}

The corpse of a man was discovered on the 13th of September in a clearing in the middle of a chestnut grove near a town in the Rhone Valley (60 km east of Lausanne). Eggs and larvae were collected at the Institute of Legal Medicine (University of Lausanne) the next day when the corpse was brought in for identification and autopsy. The entomological material was reared in the laboratory under controlled conditions. L. caesar adults appeared on the 1 st of October and $S$. caerulescens on the 6th of October. Using a thermal constant of 207 for L. caesar, the first flies laid their eggs on the body on the 13th of September. Assuming that the first $S$. caerulescens larviposited on the same day as $L$. caesar, we obtain a thermal constant of 312.3 degree-days. The man was reported missing the on 12th of September and committed suicide the same day or during the following night. Our estimation of the thermal constant based on these results is close to the thermal constant obtained from the two other cases (respectively 335.7 and 323 degree-days, mean $323.7 \pm 9.6$ (SD) degree-days). With only three cases, it is difficult to assess with certainty that we are correct, but we are probably within reasonable limits. In other cases, it may be more difficult to evaluate the time of arrival of this species, as in the following one.

\subsection{Case 107 (S. caerulescens)}

On the 8th July 2002, a corpse of a suicide victim was discovered hanging from a tree branch at the edge of a forest. His legs and knees were in contact with the ground. The altitude of the crime scene was $660 \mathrm{~m}$ a.s.l. and the temperature at the time of discovery was $20.3^{\circ} \mathrm{C}$. During our investigation at the crime scene, we collected several insects of forensic importance, in particular the blowflies $\mathrm{Ca}$. vomitoria, $L$. caesar and L. illustris, and also several other Diptera: Hydrotaea dentipes, $H$. leucostoma, $H$. irritans, Muscina prolapsa, M. assimilis, M. stabulans, Piophila sp., Sepsis sp. and Megaselia rufipes. Beetles such as Necrophorus vespilloides, $N$. investigator, Thanatophilus rugosus and Oeceoptoma thoracica were also collected. This insect material was found either on the body or within the immediate surroundings. Numerous batches of eggs and larvae were present on the corpse and within the clothes. No pupae were found even after an intensive local search. Eggs and larvae were rapidly brought back to the laboratory to be reared. Their development was checked every day, and on 19th July, $L$. caesar was first to emerge, followed 11 days later (30th of July) by $S$. caerulescens (identification confirmed through the presence of males). No adults of the latter species were collected at the crime scene. Meteorological data related to the crime scene were obtained from a nearby weather station and used to determine the daily mean temperature at the crime scene before the corpse was found. According to our development tables with regard to $L$. caesar (minimum development threshold $9{ }^{\circ} \mathrm{C}$; thermal constant 207 day-degrees) we obtained 204.7 day-degrees and we would ascertain that the flies were first present on 2nd July ( $\pm 24 \mathrm{~h}$ ) when they started to lay eggs. Other evidence from the investigation later showed that this person disappeared on the afternoon of July 1 st.

If larvae of $S$. caerulescens were deposited on the 2nd of July, total development would encompass 29 days. This means about 611.3 degree-days. Admitting a minimum development threshold of $7.4^{\circ} \mathrm{C}$ [32] we obtain a hypothetical thermal constant of 403.1 degree-days (upper limit). However, if the flies larviposited just before the discovery of the body, the entire development had lasted only 23 days, and a hypothetical thermal constant of 335.7 degree-days (lower limit) would be obtained. It is possible that $S$. caerulescens does not always arrive shortly after death has occurred.

Sarcophaga africa was found only once, as an adult in an apartment with a 7-day-old dead body. S. argyrostoma adults were also found on that occasion, as well as $L$. sericata and $P h$. regina, both in the larval stage.

One adult female (Sarcophaga sp.) was collected in a city along the Léman Lake (see below). A man just committed suicide, and one of us (CW) was there just within an hour after death. Numerous eggs were collected on the body, but no sarcophagid flies came out of the laboratory rearing. The other species involved were Ca. vicina, L. illustris and L. caesar.

Specific information: female adult specimen of Sarcophaga sp (case 85) was collected on the 13th of August 2000, at Blonay Avenue, city of Vevey (postal code 1800), in a small square. A man committed suicide at about 10:30 am. Weather was fine with an air temperature of $22.3^{\circ} \mathrm{C}$.

Sarcophaga similis was found only once, in an apartment on a 9day-old corpse (as shown by other evidence). It was associated with adults of $C a$. vicina, Ch. albiceps, $L$. caesar, L. sericata and larvae of $S$. argyrostoma. In this case, the first species to emerge from our rearing in the laboratory was $C h$. albiceps, all other species came 5 days later. This could be explained by the predation of larvae of Ch. albiceps on other species [36] or a delayed arrival of these other species.

\section{Discussion}

The flesh flies found during our investigations in Switzerland comprised five species, three of which can be considered of minor forensic importance. The reason is simple. First, we never found larvae of $S$. africa and $S$. sp. on dead bodies, only adults were collected. Second, S. similis was found only once with adults and 
larvae together with S. argyrostoma. Concerning the development of $S$. africa, Al-Misned [37] calculated the thermal constant to be $289.1 \pm 24.4$ degree-days with a lower developmental threshold of $11.0^{\circ} \mathrm{C}$. This is a characteristic of summer species, such as Lucilia spp.

Data concerning $S$. africa adults were obtained from pork meat baits in outdoor and indoor conditions in the city of Parma (Italy). This species is the dominating species larvipositing in late May [39]. According to Pérez-Moreno et al. [38], S. africa, besides provoking myiasis, can feed on decomposing matter, faeces and dead snails. However, Bänziger and Pape [40] showed that when given a choice of faeces or carrion, $S$. africa larviposits exclusively on faeces (coprobiodotic) and not on carrion.

The distribution of this species is primarily and probably originally Afrotropical, but it is currently practically cosmopolitan, although often restricted to anthropogenic habitats outside of the Afrotropics [41].

S. similis is widely distributed in the Palaearctic and Oriental regions. It is possible to rear this species from decaying beef [42]; it has been recorded as breeding in carcasses, garbage and faeces [43] as well as in moribund caterpillars [44], and it has been involved in several cases of otomyiasis in the eastern part of its distribution [45-48]. Recently, Tanaka et al. [49] showed that photoperiod is a major factor in the induction of pupal diapause in this species. During a 1-year survey in a vegetable garden in the city of Osaka [50], S. similis was captured from spring to autumn, but not in winter due to pupal diapause. This species is found in mesophytic forest habitats feeding at flowers and decaying substrates [31]. In our case, this species was found indoors. Curiously, both this species and $S$. africa were found in mixed infestations with $S$. argyrostoma.

We can qualify the two other species (S. argyrostoma and $S$. caerulescens) as being of forensic importance in our country. Moreover, only S. argyrostoma and S. caerulescens have been found more than once.

All the species collected were found during summer (with one exception in February, but only with dead flies). This is also expressed by the rather high minimum development threshold found for S. argyrostoma $\left(7.4^{\circ} \mathrm{C}\right)$ by Grassberger and Reiter [32] and for $S$. africa $\left(11.0^{\circ} \mathrm{C}\right)$ by Al-Misned [37]. We can compare this threshold temperature with those of Pr. terranovae $\left(7.8^{\circ} \mathrm{C}\right), \mathrm{L}$. sericata $\left(9^{\circ} \mathrm{C}\right)$ and $\mathrm{Ch}$. albiceps $\left(10.2^{\circ} \mathrm{C}\right)[34,35]$, which are species likewise found during summer in Switzerland. The thermal constant of $S$. argyrostoma, as calculated using the 13 present cases with a PMI estimate, was very close to the one found by Grassberger and Reiter [32] with laboratory rearing of larvae. The difference between the means (396.4-380.6 = 15.8 degree-days $)$ is about 1 day difference. This could be due to the difference between laboratory conditions and 'field' conditions, as already observed with $\mathrm{Ca}$. vicina (D. Cherix, unpublished), where competition between the different species is present. Considering the fact that small ecological differences can exist between Austrian and Swiss populations, the thermal constant estimated for S. argyrostoma ( $K=380.6 \pm 16.3$ degree-days) is probably accurate for Switzerland. In addition, in several cases we had by chance other species (blowflies) to help in evaluating the time when the first flies deposited their eggs on a corpse. When considering the 13 cases with PMI estimates, on nine occasions $S$. argyrostoma larviposited the first day or the same day as other blowfly species, three times it was a later arrival and only in one case was it an earlier arrival. According to Byrd and Castner [6], flies of the genus Sarcophaga arrive on human remains concurrently or slightly after the blowflies. They are known to fly under inclement conditions that would prevent the flight of most other flies. This could have been the explanation for case 139, but according to our meteorological data, the weather was fine.

We can therefore propose to use S. argyrostoma, in addition to other species, for the estimation of PMI. In our general analysis [9], considering the relation between species composition and environmental factors following Dolédec and Chessel [51,52], we could describe five groups of species in relation to the registered environmental factors (indoors vs. outdoors, altitude, season and urbanisation). S. argyrostoma was found in 21 cases characterised by L. sericata, L. illustris, Ch. albiceps and Pr. terranovae. L. sericata was the most frequent species (76\%) followed by Pr. terranovae (71\%). Most of these cases were found indoors, at low altitude (81\%) in summer (71\%) and in urban areas (86\%). This is probably the best quantifiable data set for $S$. argyrostoma. Interestingly, Benecke [53] mentioned that in Cologne, Germany, $S$. argyrostoma "has never been seen on corpses inside flats," which led him to consider S. argyrostoma as "a highly indicative species which tells if a corpse found in a more or less closed environment [...] was (temporarily) lying outside a flat." The Swiss cases would seem to indicate the opposite, namely that $S$. argyrostoma has a high propensity for colonising corpses found indoors. In Poland, the only forensic case involving $S$. argyrostoma is related to a corpse found indoors [54]. In any case, S. argyrostoma is clearly increasingly anthropophilic at higher latitudes, benefitting from the milder urban climate $[19,55]$.

The behaviour of males was observed during experiments conducted with pigs [9]. Males are waiting for females close to the dead pig and they indiscriminately try to mate with each fly in the area (Calliphoridae, Muscidae as well as non-conspecific Sarcophagidae). However, females were never observed depositing larvae on the pig (C. Wyss, unpublished).

Concerning S. caerulescens, we assumed, with little evidence, the same minimum development threshold of $7.4^{\circ} \mathrm{C}$ as found for $S$. argyrostoma, and a thermal constant of about 323.7 degree-days. However, this needs to be further tested with laboratory rearing of several populations of this species. This species differs from $S$. argyrostoma by showing a preference for outdoor situations. However, this has to be confirmed by more data about its ecology and behaviour, and it should be mentioned that a recent case from Finland involved $S$. caerulescens breeding in a corpse found indoors [56]. Even if we were able to calculate one PMI with reasonable accuracy, we will not recommend the use of this species until more specific information has been collected.

Finally, we strongly urge all investigators, pathologists as well as people otherwise involved in these investigations to preserve adult specimens and deposit this material (mounted and correctly labelled) in natural history museums, allowing future specialists to identify specimens and help investigators in their work.

\section{Acknowledgement}

Thanks are due to Véronique Helfer (Museum of Zoology, Lausanne) for her critical comments and constructive remarks.

\section{References}

[1] P. Mégnin, La Faune des Cadavres: Application de l'Entomologie à la Médecine Légale, Encyclopédie scientifique des aide-mémoire, Masson et Gauthier-Villars, Paris, 1894.

[2] M. Leclercq, Entomologie et Médecine Légale, Datation de la Mort, Masson, Paris, 1978.

[3] K.G.V. Smith, A Manual of Forensic Entomology, The Trustees of the British Museum (Natural History), London, 1986.

[4] E.P. Catts, N.H. Haskell, Entomology and Death: A Procedural Guide, Joyce's Print Shop, Inc, Clemson, SC, USA, 1990

[5] Z. Erzinçlioglu, Maggots Murder and Men. Memories and Reflexions of a Forensic Entomologist, Harley Books, Colchester, England, 2000.

[6] J.H. Byrd, J.L. Castner, Insects of forensic importance, in: J.H. Byrd, J.L. Castner (Eds.), Forensic Entomology: The Utility of Arthropods in Legal Investigations, CRC Press, Boca Raton, FL, USA, 2001, pp. 43-79.

[7] J.H. Byrd, J.L. Castner, Forensic Entomology: The Utility of Arthropods in Legal Investigations, 2nd ed., CRC Press, Boca Raton, FL, USA, 2009.

[8] B. Greenberg, J.C. Kunich, Entomology and the Law. Flies as Forensic Indicators, Cambridge University Press, UK, 2002. 
[9] C. Wyss, D. Cherix, Traité d'Entomologie Forensique. Les Insectes sur la Scène de Crime, Collection Sciences Forensiques, PPUR, Lausanne, 2006.

[10] D. Gennard, Forensic Entomology. An Introduction, John Wiley \& Sons Ltd, West Sussex, England, 2007

[11] J. Amemndt, M.L. Goff, C.P. Campobasso, M. Grassberger (Eds.), Current Concepts in Forensic Entomology, Springer, Berlin, 2010, , 376 pp.

[12] B. Merz, G. Bächli, J.-P. Haenni, Y. Gonseth, Diptera - Checklist, Fauna Helvetica I. Centre suisse de cartographie de la faune (CSCF) et Schweizerische Entomologische Gesellschaft, Neuchâtel/Zurich, 1998.

[13] K. Rognes, Blowflies (Diptera, Calliphoridae) of Fennoscandia and Denmark, Fauna Entomologica Scandinavica 24 (1991).

[14] K. Rognes, Family Calliphoridae, in: L. Papp, B. Darvas (Eds.), Manual of Palaearctic Diptera (vol. 3), Higher Brachycera, Science Herald, Budapest, 1998 , pp. $617-648$.

[15] M.S. Archer, M.A. Elgar, Effects of decomposition on carcass attendance in a guild of carrion-breeding flies, Medical and Veterinary Entomology 17 (2003) 263-271.

[16] L.M. Cainé, F. Corte Real, M.I. Saloña-Bordas, M. Martínez de Pancorbo, G. Lima, T. Magalhães, F. Pinheiro, DNA typing of Diptera collected from human corpses in Portugal, Forensic Science International 184 (2009) e21-e23.

[17] D. Charabidze, B. Bourel, V. Hedouin, D. Gosset, Repellent effect of some household products on fly attraction to cadavers, Forensic Science International 189 (2009) 28-33.

[18] S. Vanin, P. Tasinato, G. Ducolin, C. Terranova, S. Zancaner, M. Montisci, S.D. Ferrara, M. Turchetto, Use of Lucilia species for forensic investigations in southern Europe, Forensic Science International 177 (2008) 37-41.

[19] T. Pape, The Sarcophagidae (Diptera) of Fennoscandia and Denmark, Fauna Entomologica Scandinavica 19 (1987).

[20] T. Pape, Sarcophagidae, in: L. Papp, B. Darvas (Eds.), Manual of Palaearctic Diptera, vol. 3, Science Herald, Budapest, 1998, pp. 649-678.

[21] K. Szpila, J.G. Voss, T. Pape, A new forensic indicator for buried bodies (Diptera, Sarcophagidae, Miltogramminae), Medical and Veterinary Entomology 24 (2010) 278-283.

[22] M. Orfila, Mémoire sur les exhumations juridiques, in: Traité de Médecine Légale, 4th ed., Labé, Paris, 1848, pp. 81-165.

[23] M. Bergeret, Infanticide, momification naturelle du cadavre. Découverte du cadavre d'un enfant nouveau-né dans une cheminée où il s'était momifié. Détermination de l'époque de la naissance par la présence de nymphes et de larves d'insectes dans le cadavre et par l'étude de leurs métamorphoses, Annales d'Hygiène et de Médicine Légale 4 (1855) 442-452.

[24] A.I. Eberhardt, G. Steiner, Untersuchungen über das Schmarotzen von Sarcophaga spp. in Regenwürmern, Zeitschrift für Morphologie und Ökologie der Tiere 41 (1952) $147-160$

[25] A.I. Eberhardt, Sarcophaga carnaria als obligatorischer Regenwurmparasit, Naturwissenschaften 41 (1954) 436.

[26] A.I. Eberhardt, Untersuchungen über das Schmarotzen von Sarcophaga carnaria an Regenwürmern und Vergleich der Biologie einiger Sarcophaga Arten, Zeitschrift für Morphologie und Ökologie der Tiere 43 (1955) 616-647.

[27] E.D. Kirchberg Zucht von Sarcophaga carnaria L. (Diptera, Tachinidae) aus einer Freilandpopulation von Regenwürmern des Genus Allolobophora Eisen (Oligoch., Lumbricidae). (Zur Kenntnis der Gattung Sarcophaga Mg. III.), Anzeiger für Schädlingskunde, Pflanzenschutz und Umweltschutz 34 (1961) 6-7.

[28] F. Gregor, D. Povolny, Resultate stationärer Untersuchungen von synanthropen Fliegen in der Umgebung einer Ortschaft in der Ostslowakei, Zoologica Listy 10 (1961) 17-44

[29] K.Y. Grunin, On the biology and distribution of certain Sarcophagidae (Diptera, Sarcophagidae) in the USSR, Entomological Review, Washington 43 (1964) 36-39 (Translated from Entomologicheskoe Obozrenie 43, 71-79).

[30] F. Introna, C.P. Campobasso, A. Di Fazio, Three case studies in forensic entomology from southern Italy, Journal of Forensic Sciences 43 (1998) 210-214.

[31] D. Povolný, Y.G. Verves, The flesh-flies of Central Europe (Insecta, Diptera, Sarcophagidae), Spixiana Supplement 24 (1997).

[32] M. Grassberger, C. Reiter, Effect of temperature on development of Liopygia (=Sarcophaga) argyrostoma (Robineau-Desvoidy) (Diptera: Sarcophagidae) and its forensic implications, Journal of Forensic Sciences 47 (2002) 1-5.
[33] S. Reibe, B. Madea, How promptly do blowflies colonise fresh carcasses. A study comparing indoor with outdoor locations, Forensic Science International 195 (2010) 52-57.

[34] M.I. Marchenko, Medico-legal relevance of cadaver entomofauna for the determination of the time since death, Acta Medicinae Legalis et Socialis 38 (1988) 257-302.

[35] M.I. Marchenko, Medico-legal relevance of cadaver entomofauna for the determination of the time since death, Forensic Science International 120 (2001) 89-109.

[36] Z. Erzinçlioglu, Blowflies, Naturalists' Handbook 23, The Richmond Publishing Co. Ltd, Slough, 1996.

[37] F.A.M. Al-Misned, Of temperature on development and mortality of immature Sarcophaga (Liosarcophaga) dux Thomson (Diptera: Sarcophagidae), Journal of King Saud University. Agricultural Sciences 16 (2004) 53-60.

[38] S. Pérez-Moreno, A.M. Marcos-Garcia, S. Rojo, Comparative morphology of early stages of two Mediterranean Sarcophaga Meigen, 1826 (Diptera; Sarcophagidae) and a review of the feeding habits of Palaearctic species, Micron 37 (2006) 169-179.

[39] A. Leccese, Insects as forensic indicators: methodological aspects, Aggrawal's Internet Journal of Forensic Medicine and Toxicology 5 (2004) 26-32.

[40] H. Bänziger, T. Pape, Flowers, faeces and cadavers: natural feeding and laying habits of flesh flies in Thailand (Diptera: Sarcophagidae, Sarcophaga spp.), Journal of Natural History 38 (2004) 1677-1694.

[41] T. Pape, Catalogue of the Sarcophagidae of the world (Insecta: Diptera), Memoirs of Entomology International 8 (1996) 1-558.

[42] F. Mihályi, Rearing flies from faeces and meat infected under natural conditions, Acta Zoologica Hungarica 9 (1965) 153-164.

[43] R. Kano, K. Sato, H. Tange, Notes on the flies of medical importance in Japan (Part II). The larvae of Sarcophaga known in Japan, Japanese Journal of Experimental Medicine 21 (1951) 115-131.

[44] R. Kano, A. Kokubo, On sarcophagid flies recovered from the pine-moth, Dendrolimus spectabilis Butler (supplementary note), Japanese Journal of Sanitary Zoology 13 (1962) 229.

[45] Y. Yoneda, H. Iwami, A case of ophthalmomyiasis externa, Japanese Journal of Sanitary Zoology 32 (1981) 130-132.

[46] R. Hatsushika, Y. Hyo, T. Okino, A case study of otomyiasis caused by Parasarcophaga similis Meade 1876 (Diptera, Sarcophagidae), Kawasaki Medical Journal 14 (1988) 83-90.

[47] Y. Chigusa, K. Tanaka, H. Yokoi, Y. Matsuda, Y. Sasakai, Y. Ikadatsu, K. Bab, Two cases of otomyiasis caused by Sarcophaga peregrina and S. similis (Diptera: Sarcophagidae), Japanese Journal of Sanitary Zoology 45 (1994) 153-157.

[48] R. Hatsushika, H. Ushirogawa, Y. Iwanaga, A case study of human otomyiasis caused by Parasarcophaga similis (Meade, 1876) (Diptera: Sarcophagidae) found in Hiroshima, Japan, Kawasaki Medical Journal 28 (2002) 33-41.

[49] M. Tanaka, S.I. Tachibana, H. Numata, Sensitive stages for photoperiodic induction of pupal diapause in the flesh fly Sarcophaga similis (Meade) (Diptera: Sarcophagidae), Applied Entomology and Zoology 43 (2008) 403-407.

[50] S.I. Tachibana, H. Numata, Seasonal prevalence of blowflies and flesh flies in Osaka City, Entomological Science 9 (2006) 341-345.

[51] S. Dolédec, D. Chessel, Rythmes saisonniers et composantes stationnelles en milieu aquatique I - Description d'un plan d'observation complet par projection de variables, Acta Oecologica, Oecologia Generalis 8 (1987) 403-426.

[52] S. Dodélec, D. Chessel, Rythmes saisonniers et composantes stationnelles en milieu aquatique II - Prise en compte et élimination d'effets dans un tableau faunistique, Acta Oecologica, Oecologia Generalis 10 (1989) 207-232.

[53] M. Benecke, Six forensic entomology cases: description and commentary, Journal of Forensic Sciences 43 (1998) 797-805.

[54] A. Draber-Mońko, T. Malewski, J. Pomorski, M. Los, P. Slipinski, On the morphology and mitochondrial DNA barcoding of the flesh fly Sarcophaga (Liopygia) argyrostoma (Robineau-Desvoidy, 1830) (Diptera: Sarcophagidae) - an important species in forensic entomology, Annales Zoologici 59 (2009) 465-493.

[55] L. Hedström, Swedish insect records - report 4, Entomologisk Tidskrift 109 (1988) 139-149.

[56] J.L. Pohjoismäki, P.J. Karhunen, S. Goebeler, P. Saukko, I.E. Sääksjärvi, Indoors forensic entomology: colonization of human remains in closed environments by specific species of sarcosaprophagous flies, Forensic Science International 199 (2010) 38-42. 